\title{
Optimalisasi Pemanfataan Potensi Laut Desa Buladu Kecamatan Sumalata Timur Kabupaten Gorontalo Utara
}

\author{
Fitriane Lihawa ${ }^{1}$, Femy M. Sahami ${ }^{2}$ \\ ${ }^{1}$ Fakultas Pendidikan Matematika dan IImu Pengetahuan Alam, Universitas Negeri \\ Gorontalo, Jl. Jend. Sudirman No. 6 Dulalowo Timur, Kota Tengah, Kota Gorontalo, \\ Indonesia \\ ${ }^{2}$ Fakultas Perikanan dan IImu Kelautan Universitas Negeri Gorontalo, Jl. Jend. \\ Sudirman No. 6 Dulalowo Timur, Kota Tengah, Kota Gorontalo Indonesia \\ e-mail: fitryane.lihawa@ung.ac.id, femysahami@ung.ac.id
}

\begin{abstract}
Buladu village is one of the villages in East Sumalata, North Gorontalo Regency which is directly adjacent to the Celebes Sea. This village has marine potential and gold meaning potential, but the community prefers to work in mining. Meanwhile, gold meaning activities have negative impact on the environment. Marine potential must be utilized properly to support the community's economy and become an alternative livelihood for the community. Through this community empowerment program, it is hoped that the community can develop the potential of the sea for economic improvement and can switch from mining activities to marine productive activities. The purpose of this Thematic Kuliah Kerja Sibermas (KKS) community service program is to optimize the utilization of marine potential by making a demonstration plot for seaweed cultivation and processing of the anchovy (local name: gisau) into peanut brittle. The method applied is the transfer of knowledge and technology through participatory learning techniques and hands-on practice. The output of this activity is the discovery of community problems in seaweed cultivation and the production of processed anchovy products. The long-term target is the processed anchovy (gisau) products can become an alternative livelihood and a typical product business of Buladu Village.
\end{abstract}

Kata Kunci: anchovy; fish processing; seaweed cultivation

\begin{abstract}
Abstrak
Desa Buladu merupakan salah satu desa di Kecamatan Sumalata Timur Kabupaten Gotrontalo Utara yang berbatasan langsung dengan Laut Sulawesi. Desa ini tentu memiliki potensi laut yang dapat dimanfaatkan untuk menunjang perekonomian masyarakat, namun di sisi lain desa ini memiliki potensi pertambangan emas rakyat. Kecenderungan yang terjadi adalah masyarakat Desa Buladu lebih lebih banyak memilih bekerja di pertambangan. Sementara kegiatan pertambangan emas dapat menimbulkan dampak negatif terhadap lingkungan. Melalui program pemberdayaan masyarakat ini, diharapkan masyarakat dapat mengembangkan potensi laut untuk peningkatan ekonomi serta diharapkan pula ke depan masyarakat dapat beralih dari kegiatan pertambangan ke kegiatan produktif lainnya. Tujuan dari kegiatan pengabdian yang dikemas dalam program Kuliah Kerja Sibermas (KKS) Tematik yang
\end{abstract}


melibatkan mahasiswa dan dosen adalah ini adalah melakukan upaya optimalisasi pemanfaatan potensi laut melalui pembuatan demplot budidaya rumput laut dan pemanfaatan ikan teri (gisau) menjadi rempeyek. Metode yang diterapkan berupa transfer pengetahuan dan teknologi melalui teknik pembelajaran partisipatif dan praktek langsung dalam pembuatan demplot budidaya rumput laut dan pengolahan ikan gisau menjadi rempeyek. Luaran dari kegiatan ini adalah ditemukannya permasalahan masyarakat dalam budidaya rumput laut dan terciptanya produk olahan gisau. Target jangka panjang yang diharapkan adalah produk olahan gisau menjadi salah satu produk yang dapat menjadi mata pencaharian pencaharian alternative yang dapat menjadi usaha bisnis produk khas Desa Buladu.

Kata Kunci: ikan teri; budidaya rumput laut; pengolahan hasil perikanan

(C) 2021 Fitriane Lihawa, Femy M. Sahami

Under the license CC BY-SA 4.0

Correspondence author: Femy M. sahami, femysahami@ung.ac.id, Kota Gorontalo, Indonesia.

\section{PENDAHULUAN}

Desa Buladu merupakan salah satu desa di Kecamatan Sumalata Timur Kabupaten Gorontalo Utara. Desa ini memiliki luas wilayah 986 km2 dengan jumlah penduduk 826 yang terdiri dari 216 keluarga (Profil Desa Buladu, 2020). Desa ini terdiri dari 3 dusun yaitu Dusun Pongala, Dusun Jambura dan Dusun Kiki. Desa Buladu merupakan lbu Kota Kecamatan Sumalata Timur yang berada di pesisir laut Sulawesi. Oleh karena itu desa ini tentu saja memiliki potensi perikanan laut yang dapat menunjang perekonomian masyarakat jika dilakukan pemanfataan yang optimal, namun di Desa Buladu dan Kecamatan Sumalata Timur ini belum memiliki perikanan budidaya laut.

Berdasarkan topografi, pesisir laut Desa Buladu memiliki perairan yang cukup terlindung dari gelombang oleh adanya pulau-pulau kecil disekitarnya. Kondisi ini sebenarnya cocok untuk kegiatan budidaya termasuk budidaya rumput laut. Sebagaimana dalam (Radiarta, dkk. 2007), lokasi yang terlindung merupakan salah satu persyaratan untuk budidara rumput laut yang dapat dilihat dari berbagai aspek antara lain 
kondisi gelombang dari laut lepas. Namun kegiatan budidaya rumput laut tidak ditemukan di Desa Buladu.

Desa Buladu merupakan salah satu penghasil produks perikanan berupa ikan teri (gisau). Produk perikanan ini sering melimpah pada saat-saat tertentu. Selama ini pemanfaatan ikan teri ini oleh masyarakat hanya sebatas dikeringkan dengan cara dijemur dan dikonsumsi dalam bentuk segar. Ikan teri yang sudah kering selama ini dijual tanpa ada upaya pengolahan menjadi produk yang lebih bernilai ekonomis dan memenuhi permintaan pasar. Adanya kecenderungan masyarakat saat ini yang lebih suka produk yang siap saji dan adanya potensi pengembangan ekowisata Pulau Dionumo dapat menjadi peluang pasar yang cukup potensial. Namun, potensi ini belum dimanfaatkan oleh masyarakat Desa Buladu.

Ikan teri segar maupun kering memiliki kandungan kalsium dan protein yang tinggi. Ikan teri merupakan sumber kalsium dan protein yang muras serta banyak tersedia di Indonesia. Kalsium dan protein sangat dibutuhkan oleh tubuh dalam proses pembentukan jaringan terutama jaringan tulang dan gigi (Aryati \& Dharmayanti, 2014). Dalam Sahami dan Hamzah (2020) dinyatakan bahwa potensi perikanan jika dilakukan intervensi dan pengelolaan yang tepat dapat memberikan nilai ekonomi yang sangat menjanjikan di masa depan.

Selain potensi lautnya, desa ini memiliki pula potensi pertanian dan pertambangan emas. Masyarakat lebih cenderung memilih bekerja dipertambangan emas. Keterbatasan informasi dan kurangnya kemauan masyarakat untuk memanfaatkan sumberdaya laut merupakan permasalahan utama dalam kegiatan budidaya dan pengolahan hasil perikanan. Keramba Jaring Apung (KJA) tidak 
berfungsi sebagaimana mestinya. Keterbatasan keterampilan dan pengetahuan masyarakat ksususnya ibu-ibu dalam memanfaatkan ikan teri (gisau) kering masih kurang. Oleh karena itu pada kegiatan pengabdian ini dilakukan transfer ilmu dan teknologi tentang budidaya rumput laut dan pengolahan ikan teri.

\section{METODE PELAKSANAAN}

Kegiatan Kuliah Kerja Nyata (KKN) Tematik ini dilakukan di Desa Buladu Kecamatan Sumalata Timur Kabupaten Gorontalo Utara. Pelaksanaan kegiatan lapangan terhitung dari Tanggal 3 September sampai dengan 18 Oktober 2020. Program KKN Tematik ini dilaksanakan dengan mengutamakan prinsip pemberdayaan masyarakat lokal. Khalayak sasaran pada kegiatan ini adalah masyarakat Desa Buladu yang merupakan perwakilan dari semua dusun di Desa Buladu. Di desa ini belum terdapat kelompok yang bergerak dalam bidang usaha budidaya rumpt laut dan pengolahan ikan teri, sehingga yang menjadi target adalah masyarakat nelayan, karang taruna dan ibu-ibu PKK. Menurut Kepala Desa Buladu bahwa Ibu-ibu PKK selama ini belum memanfaatkan produk hasil perikanan. Oleh karena itu, melalui kegiatan ini dilakukan pemberdayaan terhadap lbuibu PKK. Karena lbu-ibu PKK memiliki potensi menjadi penggerak pembangunan desa tetapi perlu dilakukan pendampingan. Sebagaimana dalam Kesumasari, dkk. (2020) dinyatakan bahwa kader PKK merupakan salah satu tombak untuk perubahan dalam masyarakat.

Metode pengabdian ini dilakukan melalui model transfer ilmu dan teknologi budidaya rumput laut dan pengolahan hasil perikanan dengan 
menggunakan dengan metode pembelajaran partisipatif atau pelibatan langsung masyarakat dalam semua rangkaian kegiatan. Kegiatan budiaya rumput laut melalui pembelajaran langsung dengan membuat demplot, sedangkan kegiatan pengolahan ikan yaitu pembuatan rempeyek dari bahan baku lokal ikan teri (gisau). Pelibatan langsung meliputi seluruh rangkaian kegiatan baik budidaya (penyiapan bibit, pengikatan bibit, penanaman sampai pemeliharaan) maupun pembuatan rempeyek (penyiapan bahan baku dan bahan tambahan, pembuatan, pengemasan, dan uji coba penjualan).

Indikator keberhasilan kegiatan pelatihan ini dilihat dari kemampuan masyarakat dalam memahami teknik budidaya rumput laut dan membuat rempeyek gisau. Metode evaluasi yang digunakan untuk mengetahui tingkat keberhasilan adalah melalui observasi langsung mengenai kemampuan masyarakat dalam memahami teknik budidaya dan teknologi pengolahan gisau yang diaplikasikan melalui praktek langsung dalam pembuatan produk.

\section{HASIL DAN PEMBAHASAN}

\section{Hasil}

Kehadiran mahasiswa peserta KKS Tematik di Desa Buladu disambut baik oleh masyarakat. Adanya program ini, masyarakat memperoleh manfaat positif dari kegiatan pemberdayaan dalam membangun kemandirian dan adanya tambahan pengetahuan yang dapat menjadi peluang wirausaha yang kreatif dan mandiri. Sesuai dengan tujuan jangka panjang dari program ini adalah untuk menarik minat masyarakat untuk lebih menjadikan laut sebagai lahan untuk pencaharian utama dan akan secara perlahan meninggalkan lahan pertambangan. Berdasarkan tema KKS Tematik di Desa Buladu 
Kecamatan Sumalata Timur, program inti yang dilaksanakan meliputi demplot budidaya rumput laut dan pembuatan rempeyek gisau.

\section{Pembahasan}

\section{a. Budidaya Rumput Laut}

Rumput laut merupakan salah satu komoditas yang menjadi unggulan dalam bidang kelautan. Metode yang digunakan adalah metode long line dan bibit yang digunakan adalah Euchema cotonii. Metode ini sering digunakan dalam budiyaya rumput laut Euchema cotonii (Widowati dkk. 2015). Budidaya ini menggunakan Keramba Jaring Apung (KJA) yang tidak dimanfaatkan lagi oleh masyarakat.
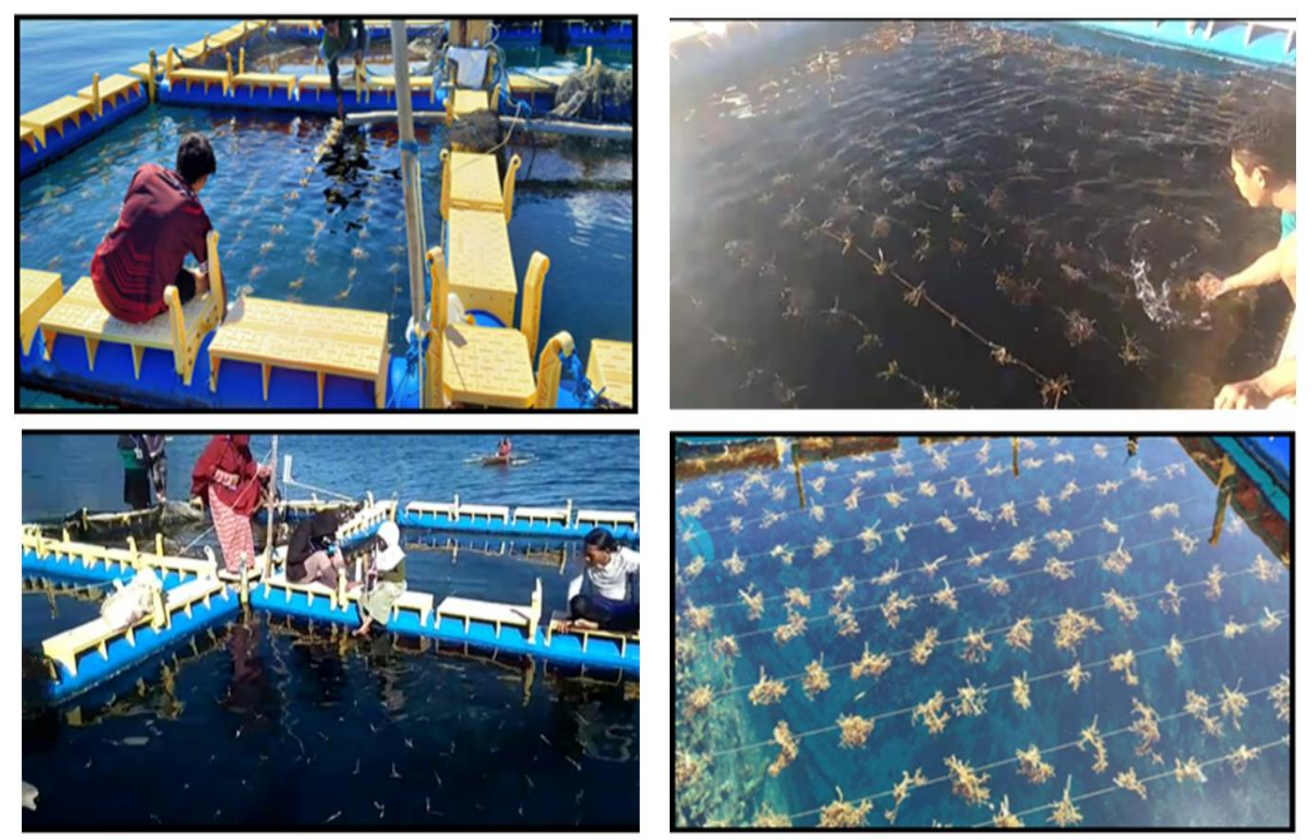

Gambar 1. Demplot budidaya rumput laut

Kegiatan budidaya rumput laut ini dari awal kegiatan yaitu tahap survey lokasi, proses penanaman sampai dengan pemeliharaan 
berjalan dengan baik. Rumput laut tumbuh dengan baik karena setiap hari (pagi dan sore) tali ris digoyang-goyang untuk menghilangkan kotoran maupun hama yang menempel. Kondisi perairan jernih dan tidak berombak. Dengan perawatan yang baik serta ditunjang dengan perawatan yang rutin, rumput laut dengan tumbuh baik. Tetapi pada hari ke-11 rumput laut habis semua dimakan penyu. Ternyata masalah ini yang menjadi kendala utama masyarakat dalam melakukan kegiatan budidaya rumput laut.

Lokasi ini berdekatan dengan beberapa pulau yang menjadi tempat konservasi penyu yaitu Pulau Raja, Pulau Mas dan Pulau Pepaya. Oleh karena itu, budidaya di perairan Buladu dan sekitarnya sering diganggu oleh penyu yang sering dating ke pulau-pulau tersebut. Sebagaimana dalam Widowati, dkk. (2015) dijelaskan bahwa salah satu penyebab kegagalan budidaya rumput laut adalah serangan hewan herbivore pemakan rumput laut seperti beronang, penyu, abalone, dan bulu babi. Kegiatan KKN Tematik ini telah memberikan pembuktian tentang permasalahan yang dihadapi oleh masyarakat.

\section{b. Pengolahan Gisau}

Ikan teri dapat dimanfaatkan sebagai asupan penting untuk mengoptimalkan pertumbuhan tulang dan gigi. Akan tetapi, dalam mengkonsumsi ikan teri ini ada beberapa hal yang perlu diperhatikan yaitu proses penyimpanan dan pengolahan (Ariati \& Dharmayanti, 2014). 

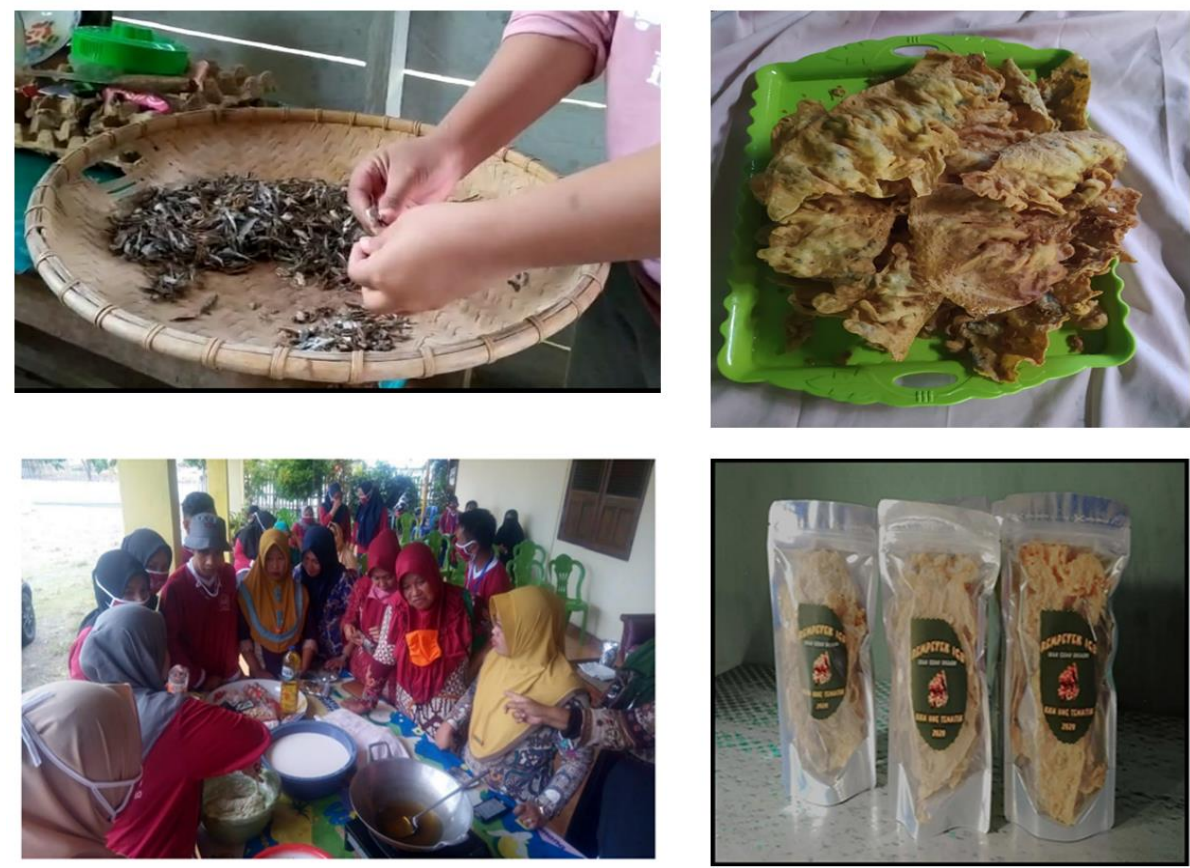

Gambar 2. Pembuatan rempeyek ikan gisau

Kegiatan optimalisasi hasil laut yang dilakukan melalui budidaya rumput laut dan pengolahan ikan teri kering (gisau) menjadi produk olahan rempeyek. Rempeyek gisau ini mem[punyai potensi untuk dikembangkan ke depan. Hal ini dapat dilihat dari hasil uji coba penjualan kepada masyarakat Desa Buladu. Kegiatan ini jika dikelola dengan baik, maka dapat membantu perekonomian masyarakat dan dapat menjadi ikon Desa Buladu. Karena selama ini belum ada yang mengolah ikan gisau menjedai rempeyek khususnya di Desa Buladu. Produk ini memiliki potensi untuk dijadikan sebagai ole-ole bagi wisatawan yang berkunjung ke Pulau Dionumo yang berada di Kecamatan Sumalata Timur. Karena berdasarkan hasil pemantauan bahwa belum ada masyarakat yang menyediakan souvenir maupun camilan ringan yang bisa dibawa pulang oleh wisatawan. Dengan 
demikian harapan jangka panjang untuk menarik minat masyarakat di Desa Buladu untuk mengoptimalkan pemanfaatan potensi laut dapat dicapai.

\section{KESIMPULAN}

Semua kegiatan berjalan dengan baik dan lancar yang ditunjang oleh keterbukaan masyarakat dalam menerima transfer pengetahuan dan mau bekerja sama serta memiliki keinginan untuk melakukan perubahan. Dalam kegiatan ini ditemui permasalahan budidaya rumput laut di Desa Buladu Kecamatan Sumalata Timur yaitu adanya predator berupa hama penyu. Solusi yang dapat dilakukan adalah dengan melakukan pengkajian lebih mendalam dengan penggunaan metode yang sesuai untuk pencegahan serangan hama penyu. Rempeyek gisau mempunyai potensi menjadi produk unggulan Desa Buladu jika dilakukan pengelolaan yang baik secara kontinyu. Harapan kedepan adalah masyarakat Desa Buladu dapat menjadikan olahan ikan gisau menjadi usaha bisnis dan dapat menjadi mata pencaharian alternative yang akan menarik mereka untuk meninggalkan kegiatan penambangan emas.

\section{UCAPAN TERIMA KASIH}

Ucapan terima kasih kepada Rektor dan Pimpinan Lembaga Penelitian dan Pengabdian pada Masyarakat (LPPM) Universitas Negeri Gorontalo yang telah mendanai kegiatan ini melalui Dana PNBP TA. 2020. Ucapan terima kasih pula kepada masyarakat dan Kepala Desa Buladu Kecamatan Sumalata Timur Kabupaten Gorontalo Utara 
yang telah menerima dana bekerja sama dalam pencapaian tujuan kegiatan ini.

\section{REFERENCES}

Aryati, E.E. \& A.W.S., Dharmayanti. (2014). Manfaat ikan teri segar (Stoleporus sp.) terhadap pertumbuhan tulang dan gigi. ODONTO Dental Journal. Volume 1, Nomor 2: 52-56.

Kesumasari, C., Kurniati, Y., Syam, A., Salam, A., \& Virani, D. (2020). Pencegahan Stunting Pada Balita Melalui Pemberdayaan Kader PKK Kecamatan Barebbo Kabupaten Bone. Jurnal Panrita Abdi, 4(3), 322 - 327.

Profil Desa Buladu, 2020. Kantor Desa Buladu Kecamatan Sumalata Timur Kabupaten Gorontalo Utara, Provinsi Gorontalo. Gorontalo.

Radiarta, I.N., T.H. Prihadi, A. Saputra, J. Haryadi, dan O. Johan. (2007). Penentuan lokasi budi daya rumput laut (Eucheuma spp.) berdasarkan parameter lingkungan di Perairan Kecamatan Moro, provinsi Kepulauan Riau. Jurnal Riset Akuakultur. Volume 2 Nomor 3.: 319-328.

Sahami, F.M., \& Hamzah, S.N. (2018). Diversifikasi Olahan Cumi Kering "Cumkring O500" Melalui KKN-PPM di Desa Olimoo'o Kecamatan Batudaa Pantai Kabupaten Gorontalo. Jurnal Panrita Abdi, 4(3), 281- 289. 